\title{
DIETARY ENERGY UTILIZATION IN RAMS BEING FED DURING THE DAY AND/OR AT NIGHT
}

\author{
M. N. Aprilliza, A. Purnomoadi and E. Rianto \\ Faculty of Animal and Agricultural Sciences, Diponegoro University, \\ Tembalang Campus, Semarang 50275 - Indonesia \\ Corresponding E-mail: amadeamozaprila@gmail.com
}

Received February 02, 2014; Accepted April 04, 2014

\begin{abstract}
ABSTRAK
Suatu penelitian telah dilakukan dengan tujuan untuk mengkaji pemanfaatan energi pakan pada domba ekor gemuk jantan yang diberi pakan pada siang dan atau malam hari. Penelitian ini menggunakan 12 ekor domba lokal jantan berumur 12-18 bulan, bobot badan awal rata-rata 27,05 2,9 $\mathrm{kg},(\mathrm{CV}=10,74 \%)$. Rancangan percobaan yang digunakan adalah rancangan acak lengkap (RAL) dengan 3 perlakuan dan 4 ulangan. Perlakuan tersebut adalah day feeding (DF): pemberian pakan pada siang hari (06.00-18.00), night feeding (NF): pemberian pakan pada malam hari (18.00-06.00), dan day and night feeding (DNF): pemberian pakan siang dan malam hari (06.00-06.00). Pemberian pakan secara ad libitum. Hasil penelitian menunjukkan bahwa waktu pemberian pakan pada siang dan/atau malam hari tidak berpengaruh nyata terhadap semua parameter yang diamati. Rata-rata konsumsi bahan kering, pertambahan bobot badan harian, konsumsi energi bruto, kecernaan energi dan deposisi energi berturut-turut adalah $1.006 \mathrm{~g} /$ hari, $75 \mathrm{~g}, 19,2 \mathrm{MJ} /$ hari, 74,0\% dari energi terkonsumsi, dan $66,2 \%$ dari energi terkonsumsi. Efisiensi pakan, efisiensi energi terkonsumsi, efisiensi energi tercerna, dan efisiensi energi terdeposisi berturut-turut adalah 7,38\%, 3,86 g pbbh/MJ, 5,24 g pbbh/MJ, dan 5,84 g pbbh/MJ. Kesimpulan penelitian ini adalah bahwa pemberian pakan pada DF dan/atau NF tidak meningkatkan pemanfaatan energi pakan pada domba ekor gemuk jantan.
\end{abstract}

Kata Kunci: domba ekor gemuk jantan, pemanfaatan energi, waktu pemberian pakan

\begin{abstract}
A study was carried out to assess dietary energy utilization in male fat-tailed sheep being fed during the day and/or at night. This study were used 12 rams of 12-18 months old with average of initial body weight of $27.05 \pm 2.9 \mathrm{~kg}(\mathrm{CV}=10.74 \%)$. The experimental design used in this study was a completely randomized design (CRD) with 3 treatments and 4 replications. The treatments were feeding during the day (06.00-18.00; DF), feeding at night (18.00-06.00; NF), and feeding all day and night (06.00-06.00; DNF). The diet was offered ad libitum. The results showed that feeding during the day and/or at night did not significantly affect $(\mathrm{P}>0.05)$ all parameters observed. The average of dry matter intake (DMI), average daily gain (ADG), gross energy intake (GEI), energy digestibility (DE) and energy metabolizability (ME) were $1006 \mathrm{~g} / \mathrm{d}, 75 \mathrm{~g} / \mathrm{d}, 19.2 \mathrm{MJ} / \mathrm{d}, 74.0 \%$ of gross energy, and $66.2 \%$ of gross energy, respectively. The feed efficiency ratio (FCR), gross energy efficiency, digestible energy efficiency, and metabolizable energy efficiency were 7.38\%, 3.86 g ADG/MJ, 5.24 g ADG/MJ, and 5.84 $\mathrm{g} \mathrm{ADG} / \mathrm{MJ}$, respectively. It is concluded that time of feeding did not affect the dietary energy utilization in local rams.
\end{abstract}

Keyword: sheep, energy utilization, feeding time 


\section{INTRODUCTION}

Animals live in the tropics get heat load from the environment, especially during the day due to the high ambient temperature (Rianto, 2001; AlTamimi, 2007). Bhattacharya and Husein (1974) reported that at $32{ }^{\circ} \mathrm{C}$ and $98 \%$ relative humidity, lambs would decrease feed intake and nutrition utilization.

Previous study showed that feeding at night increased energy utilization in lambs, because of increasing in nutrients digestibility (Hongyantarachai et al., 1989; Denek et al., 2006). Gaughan et al. (2002) reported that night feeding was able to decrease heat load and reduce lost energy for thermoregulation (Aharoni et al., 2005). Isroli et al. (2004) reported that physiological responses of lambs would be higher in high ambient temperature to maintain their homeostatic.

Based on above argumentation, it was considered to be important to study the effect of feeding at night compared to feeding during the day and/or at night on the energy utilization to support the production of local rams. The aim of this study was to assess the efficiency of energy utilization in male fat tail sheep fed during the day and/or at night. The results of this study were expected to improve production of sheep through feeding management.

\section{MATERIALS AND METHODS}

\section{Animals, Diets and Treatments}

Twelve rams, aged 12-18 months, weighed $27.05 \pm 2.9 \mathrm{~kg}(\mathrm{CV}=10.74 \%)$ were used in this study. The rams were kept in individual pens equipped with feed buckets and drinking water piles. They were fed complete feed (pellets) consisting of wheat straw, molasses, cassava, rice bran and soybean meal. Feed composition and nutrient content of feed that used in this study are presented in Table 1.The treatments applied were time of feeding, i.e. day feeding (06.00 -18.00, $\mathrm{DF})$, night feeding (18.00-06.00, NF), day and night feeding (06.00-6.00, DNF).

\section{Experimental Procedures}

The rams were firstly adapted to the environment and time of feeding for 2 weeks. The rams were weighed prior the data collection period. Feed was offered to the rams according the treatment applied. For rams of DF, the feed was offered in 12 hours a day, i.e. from 06.00 to
18.00 , then it was pulled. For rams of NF, the feed was offered, i.e. from 18.00 to 06.00 , then it was pulled. For rams of DNF, the feed was offered in 24 hours a day. During the feeding time, the feed was ad libitum. The feed refusals of DF was weighed everyday at 18.00; while those of NF and DNF were weighed everyday at 06.00. Feed samples were daily collected at amount of 100 grams for dry matter content analysis.

In the $5^{\text {th }}$ week of data collection period, faeces and urine were collected for 7 days. The faeces and urine collected were homogenized and sampled for energy content analysis.

In the $6^{\text {th }}$ week, methane of rumen exhaled via mouth was measured using $\mathrm{CH}_{4}$ Analyzer (Horiba Ltd., Japan) and Airflow Meter, which was connected to a computer. Measurements were performed for 10 minutes at intervals of 3 hours for 2 x 24 hours (Kawashima et al., 2001).

During the data collection period, the rams were weighed every week to determine their body weight to adjust the feed given in frther week. The live weight gains of the rams were obtained from the difference between the live weight in week 10 and the week 0 .

\section{Parameter Measured}

The parameters measured in this study were average daily gain, dry matter intake, gross energy, fecal energy, urinary energy, methane energy, digestible energy, metabolizable energy, feed efficiency, efficiency of gross energy, efficiency of digestible energy, and efficiency of metabolizable energy.

\section{Statistical analysis}

The data obtained were analyzed statistically using ANOVA procedure appropiate for completely random design. After a significant $\mathrm{F}$ test $(\mathrm{P}<0.05)$, Duncan's multiple range test was used to inspect differences among group means.

\section{RESULTS AND DISCUSSIONS}

\section{Performance of Rams}

Dry matter intake (DMI) and average daily gain (ADG) of rams are presented in Table 2. Time of feeding did not have significant effect on the DMI, because there was no big difference in ambient temperature between day at night time, i.e. $27.7^{\circ} \mathrm{C}$ and $25.2^{\circ} \mathrm{C}$ so that the heat load that animal received were relatively same.

This finding was in agreement with the study of Rianto (1997) that DMI of lambs was not 
Tabel 1. Feed Composition and Nutrient Content

\begin{tabular}{lc}
\hline \multicolumn{1}{c}{ Feed Ingredient } & $\begin{array}{c}\text { Composition/ } \\
\text { Content }\end{array}$ \\
\hline A. Feed Composition & \\
Wheat straw (\%) & 21 \\
Molases (\%) & 1 \\
Cassava (\%) & 10 \\
Rice bran (\%) & 42 \\
Soy bean meal (\%) & 26 \\
B. Nutrient content (100\% DM) : & \\
Dry Matter (\%) & 84.14 \\
Organic Matter (\%) & 90.29 \\
Crude Protein (\%) & 16.64 \\
Crude Fiber (\%) & 22.51 \\
Extract Ether (\%) & 3.08 \\
Gross Energy (MJ/kg) & 19.09 \\
Total Digestible Nutrients (\%) & 66.41 \\
\hline
\end{tabular}

significantly reduced when day/night temperature was elevated from $20^{\circ} \mathrm{C} / 20^{\circ} \mathrm{C}$ to $47^{\circ} \mathrm{C} / 39^{\circ} \mathrm{C}$. Rianto et al. (2005) reported that DMI of merino lambs weiged $33 \mathrm{~kg}$ lived both at $20^{\circ} \mathrm{C}$ and $40^{\circ} \mathrm{C} / 32^{\circ} \mathrm{C}$ were able to consume up to 1105 $\mathrm{g} /$ day. This result suggested that ambient temperature did not cause any decrease in DMI until quite high levels of temperature were reached. The increase or decrease in feed intake is related to animal's efforts in increase or decrease body heat production when the ambient temperature is low or high. The DMI in study was $1006 \mathrm{~g} /$ day or $3.75 \%$ of body weight. This was lower than Purbowati et al. (2008), who reported that rams fed complete feeds composed of agroindustry and agricultural by product required $5.31 \%$ DMI of body weight.

Average daily gain among the treatments showed no significant difference, averaged $75 \mathrm{~g}$. This was because the lambs had no difference in DMI. This finding was lower than previous research; Rianto et al. (2004) reported that average daily gain of animals fed tofu cake (CP:13.67, CF:18.17, and TDN:63.52) was $120 \mathrm{~g}$. This finding indicated that different nutrients contain of diet would affect live weight gain in animals.

\section{Energy Utilization}

The results showed that the average of energy utilization were not significantly different. The results of this study indicate that time of feeding had no effect $(\mathrm{P}>0.05)$ on utilization of energy. Dietary energy utilization in rams are presented in Table 3.

The total energy intake of each treatment (DF, NF, and DNF), showed no significant difference. The average of energy intake was $19.19 \mathrm{MJ} /$ day. This was because DMI was not significantly different (Table 3). Metabolizable energy intake in this research was not significantly different, with the average of 12.89 $\mathrm{MJ} /$ day. This condition was also due to the no difference in ambient temperature during the day and at night. The non-difference in ambient temperature during the day and at night led to similar animal's physiological condition, which in turn caused the lambs to have similar body heat production.

Fecal energy of DF, NF, and DNF was not significantly different. The average of fecal energy in this research was $25.97 \%$ of gross energy intake. Feces was the largest energy that was lost from the feed. The fecal energy in this study was lower than that stated by Purnomoadi et al. (2005), being $30.80-37.10 \%$ of the energy intake. This was confirmed by the lowest nutrient digestibility in previous study, i.e. $67.23 \%$ (Purnomoadi et al., 2005), whereas in this study was $68.58 \%$, thereby reducing energy through feces.

Urinary energy excretion was not significantly different $(\mathrm{P}>0.05)$ among the treatments. The average of urinary energy was $0.28 \mathrm{MJ} /$ day or $1.16 \%$ of gross energy intake. The content of nitrogen in feed closely related to the urinary energy, as the energy released from the metabolism of amino acids, where the relation to the excess of nitrogen in the form of urea feed is wasted as urine. Urinary energy in this study (1.16\% of gross energy intake), was lower than the study reported by von Keyserlingk and Mathison (1993), that the urinar energy or animal during heat stress was $1.55 \%$ of the energy consumed, whereas in normal condition was $1.23 \%$. Urinary energy was affected by animal metabolic and the reducing levels of metabolism, causing a decrease in the urine volume (Edey, 1983).

Methane energy in this research were not 
Table 2. Dry Matter Intake and Average Daily Gain of Rams

\begin{tabular}{lrrrrr}
\hline & \multicolumn{4}{c}{ Treatment } & \multirow{2}{*}{ Parameter } \\
\cline { 2 - 5 } \multicolumn{1}{c}{} & \multicolumn{1}{c}{ DF } & NF & DNF & Average & P Value \\
\hline DMI (g/day) & 1078 & 865 & 1074 & 1006 & 0.900 \\
ADG (g) & 66 & 60 & 100 & 75 & 0.291 \\
\hline
\end{tabular}

No signifant differences at $5 \%$. DMI: Dry matter intake; ADG: Average daily gain.

Table 3.The Effect of Time of Feeding on Energy Utilization in Rams

\begin{tabular}{lccccc}
\hline \multirow{2}{*}{ Parameter } & \multicolumn{5}{c}{ Treatment } \\
\cline { 2 - 5 } & \multicolumn{1}{c}{ DF } & NF & DNF & Average & \\
\hline Gross Energy (MJ/day) & 20.59 & 16.50 & 20.50 & 19.19 & 0.900 \\
Energy Utilization (MJ/day) & & & & & \\
$\quad$ Feces & 4.97 & 4.38 & 5.26 & 4.87 & 0.806 \\
$\quad$ Urine & 0.45 & 0.25 & 0.12 & 0.28 & 0.273 \\
$\quad$ Methane & 1.58 & 1.15 & 1.13 & 1.29 & 0.135 \\
Energy Loss Through (\%) & & & & & \\
$\quad$ Feces & 25.46 & 26.77 & 25.68 & 25.97 & 0.923 \\
$\quad$ Urine & 1.29 & 1.56 & 0.63 & 1.16 & 0.173 \\
$\quad$ Methane & 7.92 & 6.04 & 5.90 & 6.62 & 0.342 \\
Digestible Energy (MJ/day) & 15.59 & 12.10 & 15.24 & 14.32 & 0.923 \\
Digestible Energy(\%) & 74.53 & 73.2 & 74.32 & 74.03 & 0.835 \\
Metabolizable Energy (MJ/day) & 13.94 & 10.80 & 13.86 & 12.89 & 0.901 \\
Metabolizable Energy (\%) & 65.31 & 65.62 & 67.79 & 66.24 & 0.644 \\
\hline
\end{tabular}

No signifant differences at $5 \%$.

significant differences, its average was $6.62 \%$ of gross energy. The finding was higher than the reported data by van Koyserlingkand Mathison (1993), in which the average of methane energy was $6 \%$ of the energy consumed. Feeding at day and/or night did not cause different of dry matter intake and feed digestibility, the average of 1006 $\mathrm{g} /$ day and $68.58 \%$, respectively. The increasing of feed consumption will increase methane gas, the process of feed digestion in the rumen also increased because of consumption increased. The end result of of feed digestion process were methane, carbon dioxide, and VFA. Methane energy was influenced by several factors, i.e. the quality of feed, crude fiber content, feed intake, and feed digestibility (Kurihara et al., 1997). Although the ambient temperature and variations were able to affect the amount of methane gas production from various kinds of feed (Moss, 2002), but the data in this study were not significant different because of the type of feed was same for all treatments.

There was no significant difference among the treatments in DE intake, the average was $74.03 \%$. This is presumably due to feeding at night did not influence the digestibility and DMI, and feed metabolism processes in the animal body. Rianto (1997) reported that energy 
digestibility of cross Merino lambs live at $20^{\circ} \mathrm{C}$ and $30^{\circ} \mathrm{C}$ were $69.70 \%$ and $70.70 \%$ of gross energy, respectively. Feed intake will decrease in heat stress condition, but in common not affect digestibility (Rianto et al., 2005). Factors affecting digestibility of energy were the quality of the feed, the amount of dry matter consumed, feed flow rate in the gastrointestinal tract (Ranjhan and Pathak, 1989).

Metabolizable energy in this research showed no significant differences $(\mathrm{P}>0.05)$ among the treatments, the average was 12.89 or $66.24 \%$ of gross energy. The lack of difference in metabolizable energy affected by fact that feeding at night did not reduce heat load, so that rams being fed during the day and/or at night had similar requirement of metabolizable energy. Having similar DMI, the rams had similar energy digestibility and matabolizability. Energy metabolizability in this research $(66.24 \%$ of gross energy) was similar to the finding of Bhattacharya and Husein (1974) that energy metabolizability of Awasi lambs was $65.61 \%$ of gross energy. Mohamed (2012), reported that the metabolizable energy of Desert lambs fed medicago sativa in summer season was $8.48 \mathrm{MJ} /$ day.

\section{Efficiency of Energy Utilization}

The data of feed efficiency ratio (FCR), efficiency of gross energy (GE), efficiency of digestible energy (DE), and efficiency of metabolizable energy (ME) are presented in Table 4. The results of this study showed no significant effect of feeding during the day and/or at night on efficiency of metabolizable energy $(\mathrm{P}>0.05)$. The lack impact of feeding during the day and/or at night to efficiency of energy utilization in this study due to no differences in nutrient and energy digestibility. Having similar nutrient and energy digestibility, animals also had similar ability in utilizing energy for productive purpose (e.g. ADG) and that efficiency of energy utilization would be similar.

There was no significant difference in FCR among the treatments, the average was $7,38 \%$. This was so because no differences in DMI and ADG, so that rams had similar feed utilization. This feed efficiency was higher than that of Setyaningsih et al. (2008) who reported that feed efficiency of rams was $6.77 \%$. This difference might be affected by different quality of feed given in this study and previous study.

The average of efficiency of GE, DE, and $\mathrm{ME}$ were 3.86, 5.24, and $5.84 \mathrm{~g}$ ADG/MJ, respectively. The efficiency of GE in this study was lower than that of Setyaningsih et al. (2008), who reported that efficiency of GE of sheep fed $1.5 \%$ of maintenance was $4.25 \mathrm{~g} \mathrm{ADG} / \mathrm{MJ}$. The efficiency of digestible energy in this study was lower than previous study that of Rianto (1997) who reported that cross Merino lambs live at $30 \circ \mathrm{C}$ was $7.75 \mathrm{~g}$ ADG/MJ. Purbowati et al. (2008) reported that efficiency of ME of sheep fed complete feed (CP: 14.48, TDN: 50.46) was 26.40 $\mathrm{g}$ ADG/MJ. The low value of energy efficiency in this study compared to previous studies might be caused by differences in the feed quality and the breed of the sheep that were used in the research.

\section{CONCLUSION}

Feeding during the day and/or at night was not alter the efficiency of dietary energy utilization in local rams. Therefore, feeding

Table 4. Feed Efficiency, Efficiency of Energy Consumed, Efficiency of Digestible Energy, and Efficiency of Metabolizable Energy

\begin{tabular}{|c|c|c|c|c|c|}
\hline \multirow{2}{*}{ Parameter } & \multicolumn{4}{|c|}{ Treatment } & \multirow{2}{*}{ P Value } \\
\hline & $\mathrm{DF}$ & NF & DNF & Average & \\
\hline Feed Efficiency Ratio (\%) & 5.58 & 7.40 & 9.15 & 7.38 & 0.182 \\
\hline \multicolumn{6}{|c|}{ Efficiency of Energy (g ADG/MJ) } \\
\hline Gross energy & 2.92 & 3.88 & 4.79 & 3.86 & 0.182 \\
\hline Digestible energy & 3.89 & 5.38 & 6.45 & 5.24 & 0.178 \\
\hline Metabolizable energy & 4.41 & 6.01 & 7.11 & 5.84 & 0.203 \\
\hline
\end{tabular}

No significant differences at $5 \%$. Data points are mean value based on fourplicate determination 
during the day and night was considered as reasonable choice to be applied for fat tailed sheep, in order to the rams were able to access the feed all along the day and to increase its energy utilization.

\section{REFERENCES}

Aharoni, Y., A. Brosh and Y. Harari. 2005. Night feesing for high-yielding dairy cows in hot weather: effects on intake, milk yield and energy expenditure. Livest. Prod. Sci. 92(3):207-219.

Al-Tamimi, H. J. 2007. Thermoregulatory response of goat kids subjected to heat stress. Small Rum. Res. 71: 280-285.

Bhattacharya, A. N. and F. Hussain. 1974. Intake and utilization of nutrient in sheep fed different levels of roughage under heat stress. J. Anim. Sci. 38: 877-885.

Denek, N., A. Can, S. Tufenk, K. Yazgan, H. Ipek, and. M. Iriadam. 2006. The effect of heat load on nutrient utilization and blood parameters of Awassi ram lambs fed different types and levels of forages. Small Rum. Res. 63: 156-161.

Edey, T. N. 1983. Tropical Sheep and Goat Production. Published by Australian University International Development Program (AUIDP), Canberra.

Gaughan, J. B., T. L. Mader, S. M. Holt, G. L. Hahn and B. A Young. 2002. Review of current assesmentof cattle and microclimate during periods of high heat load. Anim. Prod. Australia. 24:77-80 .

Hongyantarachai, S., G. Nithichai, N. Wongsuwan, S. Prasanpanich, S. Siwichai, S. Pratumsuwan, T. Tasapanon and B. R. Watkin. 1989. The Effects of Grazing versus Indoor Feeding during the Day on Milk Production in Thailand. J. Trop. Grass. Thailand. 7:8-14.

Isroli., S. A. B. Santoso and N. Haryati. 2004. Respon termoregulasi dan kadar urea darah domba garut betina dewasa yang dipelihara di dataran tinggi terhadap pencukuran wool. J. Indonesian Trop. Anim. Agric. 2:110-114.

Kawashima, T., W. Sumamal, F. Terada and M. Shibata. 2001. Respiration trial system using ventilated flow-through method with facemask. JIRCAS Journal, 9: 53-74.

Kurihara, M., S. Takahashi and T. Kume. 1997. The effects of environmental temperature on the energy metabolism of lactating cows given silage and hay. Anim. Sci. Technol. Japan. 63:831-839..

Mohamed, S. S. 2012. Effect of level of feeding season on rectal temperature and blood metabolites in Desert rams (Ovisaries). Acad. J. Nut. 1(2):14-18.

Moss, A. R. 1993. Methane. Chalcombe Publications. United Kingdom.

Purbowati, E., C. I. Sutrisno, E. Baliarti, S. P. S. Budhi and W. Lestariana. 2008. Energy utilization of complete feed with different protein-energy levels in Male Local lamb on feedelot system. J. Indonesian Trop. Anim. Agric. 33(1): 59-65

Purnomoadi, A., Yusman, E. Rianto and M. Kurihara. 2005. The energy utilization of Garut sheep fed tofu cake biscuit as concentrate substitution. Proceedings of 5th AINI Seminar. Malang, August $10^{\text {th }}, 2005$. P. 316-320.

Ranjhan, S. K. and N. N. Pathak. 1989. Management and Feeding of Buffaloes. Vicas Publishing House, PVT Ltd., New Delhi.

Rianto, E. 1997. The Effect of Heat Stress and Water Intake Restriction on Sheep Production. PhD Thesis. Department of Animal Science, Faculty of the Sciences, University of New England, Armidale.

Rianto, E. 2001. The Effect of heat stress and water intake on ruminant production:a review. J. Indonesian Trop. Anim. Agric. 26(3): 104-110.

Rianto, E., M. Budiharto and M. Arifin. 2004. Proportion of muscle, bone, and fat of carcass Male Thin Tail Sheep fed tofu by product. Proceedings, The $1^{\text {st }}$ National Seminar of Animal Agriculture and Veterinary Technology, Bogor, August 4-5, 2004. P. 309-313.

Rianto, E., C.J. Thwaites and J.V. Nolan. 2005. The effect of ambient temperature and water availability on feed digestibility, rumen microbial nitrogen production, and rumen condition in sheep. Bulletin of Anim.Sci. 29 (1):10-18.

Setyaningsih, K., G. Mahesti, A. R. Setyawan, D. Rahmadi, A. Purnomoadi and E. Rianto. 2008. Energy conversion of Indigenous rams as various body weight an 1.5 maintenance level of feeding. Proceedings, The $5^{\text {th }}$ National Seminar of Animal Agriculture and Veterinary Technology, 
Bogor, November 11-12, 2008. P. 473-476.

Von Keyserlingk, G. E. M. and G. W. Mathison.

1993. The effect of ruminal scape protein and ambient temperature on the efficiency of utilization of metabolizable energy by lambs. J. Anim. Sci. 71:2206-2217. 